\title{
TRANSPARENCY AND THE DESIRES OF THE HEART: A CONSTRUCTIVE CRITIQUE OF STUMP'S THEODICY
}

\author{
ADAM GREEN
}

University of Innsbruck

For many, Eleonore Stump's Wandering in Darkness represents not only a major work on the problem of evil but a profoundly human and orthodox one as well. ${ }^{1}$ To give the briefest of summaries, Stump defends the claim that the purpose of life is eternal, loving communion with the divine and that, in His providence, God uses the suffering of His creatures to promote interpersonal closeness with Himself and to minimize distance with His creatures. Suffering is not a matter solely of what is absolutely necessary for human flourishing but also a matter of what one sets one's heart on, one's 'desires of the heart', and the good to which divine providence is ordered enfolds the desires of our hearts as well.

In what follows, I will bring out a theme that pervades the background of Stump's book. She claims that the nature of suffering and the benefits that can defeat suffering each fail to be transparent to human beings. She uses this claim to negotiate a kind of truce with the proponents of sceptical theism and to defend her otherwise controversial claims about God's commitment to giving us the desires of our heart. I will argue that a more nuanced view of transparency is called for than Stump utilizes in her book and that a more nuanced view has importance both for the purposes to which she puts her claims about transparency as well as the content of her theodicy.

I.

Stump says that we should 'understand suffering in terms of what we care about' (p. 10). Suffering is not identical with pain (pp. 5ff.) or the violation

\footnotetext{
${ }^{1}$ Eleonore Stump, Wandering in Darkness: Narrative and the Problem of Suffering (New York: Oxford University Press, 2010).
} 
of one's will (p. 8). Following Aristotle's view that every human being seeks after eudaimonia, even if he or she doesn't know what makes for eudaimonia, Stump says that we all care about our objective flourishing but, in addition to that, she points out that we also care about 'what has great value for [us] in virtue of [our] commitment to it' (p. 10). In other words, we also care about the desires of our heart whether or not those desires are related to objective flourishing. Suffering occurs whenever either one's flourishing or one's heart's desires are damaged or undercut.

Stump points out that ' $\mathrm{n}$ ] othing guarantees that a person will be consciously aware of what constitutes his own flourishing or of what the desires of his heart are' (p. 11). Furthermore, one cannot guarantee that one will recognize when either is fulfilled. By way of analogy, Stump draws our attention to the way in which someone who appears healthy may actually have cancer and someone who has gone through treatment for cancer might look very sick while being free of disease (p. 12). Valuing health does not imply that one can discern its presence. Stump goes so far as to suppose that someone could receive what he cares most about without recognizing that fact. Stump uses the example of Victor Klemperer who was passionately committed to writing an academic book on French literature which Klemperer thought would be very important (p. 12). His efforts were stymied by the repressions of the Nazis. Klemperer's diaries, in which he vents his anguish at being deprived of his life's work, would become highly regarded literary works themselves. Stump claims that the right way to view this case is that Klemperer received his heart's desire, the desire to write a great book, but he was not aware of this fact.

Stump concludes that, since one can be ignorant about whether one is flourishing and whether one has one's heart's desire, 'the account of suffering I have argued for here implies that a human being can suffer without knowing that she is suffering, and that she can think that she suffers when she does not.' (p. 12) Stump recognizes that this claim will be counterintuitive. She argues that the counterintuitiveness arises from conflating pain and suffering (p. 5). Pain is often thought to be transparent, but suffering is not transparent. ${ }^{2}$ When one is in pain, one is aware that one is in pain. Stump never argues that the things that defeat pain are transparent, but it is not hard to argue that they have at

${ }^{2}$ It is worth noting that Stump repeatedly puts a reference in her footnotes to Timothy Williamson's denial of the transparency of pain as well, cf. p. 625, n. 131. 
least a derived transparency. Since pain is transparent, one can often tell whether it is still there 'just by looking' as it were. Since suffering is not transparent, however, benefits that remove suffering will not have derived transparency. Thus, Stump takes it to be established that 'neither suffering nor the benefits defeating suffering are transparent' (p. 413), and, in the second half of her book, she makes clear that she thinks not being transparent is equivalent to being 'opaque' (pp. 373, 408, 409, 413, 468).

Stump's claims about the transparency of suffering and its defeat show up in a number of places in her book. Notably, she uses her claim about transparency to maintain a nuanced relationship with sceptical theism. Sceptical theism is a position on the problem of evil that an increasing number of theists in academia are taking, according to which human beings are not in a position to tell whether a good God and the evils of this world could coexist. ${ }^{3}$ God is a being of another magnitude. As the Bible says, 'His ways are higher than our ways' and 'His ways are not our ways' (Isa 55:8-9). Human beings, the sceptical theist maintains, are not in a position to tell what reasons such a being might have to allow evil anymore than an infant might understand why its mother consents to its having a painful medical treatment. Sceptical theism comes in stronger and weaker varieties. A weaker version could claim, for instance, that the evils we find in the world are significant but insufficient evidence that God doesn't exist, and a strong version could go so far as to claim that the evils of this world do not constitute any evidence whatsoever as to whether a good and loving God exists.

At first glance, Stump's theodicy does not fit very well with the sceptical trend in theistic treatments of the problem of evil. She says a lot about what reasons a good and loving God has for allowing evils on the Christian story. Moreover, she requires that God be in the business of defeating evils and these evils that need defeating are largely determined by what we care about. Even worse, what we care about is partly a function of what we freely choose to care about and not simply a matter of what God has programmed us to care about. Whereas the ethos of sceptical theism is to stress the transcendence and ineffability of God, Stump's theodicy stresses the desire of God to be intimate with us.

\footnotetext{
${ }^{3}$ For an overview of sceptical theist positions, see Justin McBrayer, 'Skeptical Theism', Philosophy Compass, 5(7) (2010), 1-13. The highest concentration of seminal papers on the topic can perhaps be found in The Evidential Argument from Evil, ed. by Daniel Howard-Snyder (Bloomington: Indiana University Press, 2009).
} 
Despite the prima facie tension between Stump's theodicy and sceptical theism, she thinks the two are complementary. Stump claims that sceptical theism can be 'a fallback position for theodicists' such as herself (p. 15). The theodicist performs the equivalent of a thought experiment that may, in fact, fail to prove anything about the actual world due to sceptical considerations while nonetheless being useful. Moreover, insofar as it derives its content from revelation in the form of biblical source material, her theodicy is consistent with taking a sceptical approach to attempts to reconstruct God's reasons for allowing evil apart from revelation (pp. 14-15).

These considerations alone might not be enough to assuage the sceptical theist, however. Thought experiments are judged successful or not based on human intuition. A human being must make a judgment about what she thinks is possible or plausible. A sceptical theist will be inclined to deny that a human being has any such power to judge possible worlds when it comes to the divine and evil. Likewise, though sceptical theists are not likely to object to a distinction between revelation and natural reason, they will object to the idea that what is revealed in revelation is the sort of thing that human beings can measure against the evils of the world so as to judge whether or not the God as putatively revealed is likely to exist or not.

What does count as a true peace-making move on Stump's part, however, is her claim that 'there is a much more mundane reason for being doubtful about our ability to discern the morally sufficient reason justifying any particular case of human suffering [than that provided by skeptical theism]'. And what reason is that? '[N]either the suffering nor the benefits that could defeat it are transparent to us.' (p. 14) It is unsurprising that Stump spends much more space emphasizing this part of her view when comparing her view to sceptical theism than she spends on revelation or the status of theodical thought experiments. The transparency claim allows her to agree with the sceptical theist on his most basic conviction, that human beings aren't in a position to tell that God doesn't exist given the evils they experience. For, if one cannot tell who is suffering and whose suffering is defeated, one cannot reason from particular evils to the likelihood of God's nonexistence.

Stump also uses transparency to defend her claim that God is in the business of giving us the desires of our heart. Return to the example of Victor Klemperer. Klemperer seems to think that the desire of his heart is to write a great book about French literature. He is pained that the 
ascent of the Nazis to power deprives him of his desire. If desires of the heart were transparent, then he would surely be right. He was being deprived of what he surely seems to care greatly about. Furthermore, Klemperer's situation is by no means anomalous. It often happens that people don't get what they appear to care the most about, even when such deprivation is not a consequence of some wrongful action on their part. Every parent who's lost a child, every victim of a debilitating and shameful illness, everyone who finds themselves bored and listless in life can bear witness to the universality of the suffering borne of caring about things that never happen or are taken away. The supposed existence of a superlatively great afterlife doesn't make sense of why one must live day to day without the thing one wants most in this life.

The existence of the Klemperers of the world poses a significant obstacle to a theodicy that wants to affirm not just that the righteous 'get theirs in the end', but that God is desirous of the closest intimacy with every human being here and now. As we know, Stump actually claims the case of Klemperer as an example of how God does providently work so as to provide the desires of the heart. Klemperer's diary, in which he records his despair at not being able to produce his book, becomes a great work of literature itself. Stump says,

Presumably, if Klemperer had been offered the choice of writing a book that added to the existing secondary literature on a limited period in French literary history or writing a book that is one of the greatest German works of any kind, he would have wanted the latter much more than the former; and he would have recognized the desire for the latter as a version of the desire for the former. (p. 436)

These are bold claims about the true nature of Klemperer's desires, but notice that they would make no sense if the nature of Klemperer's suffering and the necessary means of defeating it were transparent. If Klemperer's desire was transparent, we would have no choice but to accept that Klemperer suffers the loss of a desire of his heart that is not defeated. The same would hold for the myriad other cases of frustrated desire. If the desires of the heart and their fulfilment are not transparent, this creates the possibility that God really is in the business of providing our hearts' desires despite the prevalence of people who seem deprived of those desires for no good reason. ${ }^{4}$

${ }^{4}$ Stump also uses her claims about transparency to block an objection having to do with the ethical implications of her theodicy (pp. 412-413) as well as to defend limiting her treatment of evil to fully functional adults (p. 477). 
II.

Having explicated Stump's claims about the lack of transparency of one's suffering and the benefits that could defeat that suffering, this section will show that transparency is not quite what Stump makes it out to be.

Transparency is a degreed property. Something can be more transparent or less, and more opaque or less. One does sometimes speak as if transparency or opacity are not degreed. One might assert without qualification that a piece of obsidian is opaque or that a windowpane is transparent. Nevertheless, it is equally sensible to ask how transparent something is. When used without qualification, it is often understood that there is some standard against which something counts as transparent or opaque. For a piece of glass, the key may be whether one can see through it. For a comment, it may be whether one can discern what the comment means without having to think much about it. The degreed nature of transparency is only drawn attention to when it makes some practical difference. If the queen is visiting, it might matter how transparent the glass is and whether a little more polish might make it more so. Likewise, if one wants to communicate a message to one's spouse and not one's child, one will pay attention to just how opaque one's comment is.

In the context of Stump's work, it is worthy of note that she makes rather extensive claims about what is not transparent, but it is not plausible that things like suffering and desire are completely opaque either, certainly not in normal cases. It is one thing to claim that one can be wrong about what one truly cares about, or for one to claim that it is possible for one not to know what it is that one desires. It is quite another to claim that one has no clue. In other words, it does not follow from something's not being transparent to one that one's subjective perception of the matter does not constrain what may be claimed about it. A lack of transparency of even a high degree does not entail that something is completely opaque.

Suppose, for instance, that Tommy the teenager thinks he's in love with Betty, the school nurse. It could well be that whether Tommy is really in love with Betty is not transparent to Tommy. In fact, let us suppose that Tommy is not really in love but instead has a youthful crush that falls short of love for some reason. Despite his confusion on the question of whether or not he loves Betty, the nature of his attitude toward Betty is not completely opaque to Tommy. If Freddy the friendly neighbourhood Freudian gives Tommy impressive sounding reasons for 
thinking Tommy actually hates Betty, Tommy might well trump Freddy's assertions on the basis of Tommy's awareness of his own internal states. Tommy tells Freddy that he knows that Freddy is wrong, and Tommy does know this. The exact nature of Tommy's feeling is not transparent to him, but he has some grasp of what his feelings are and what they are not.

Thus, one complication for Stump's account is that one cannot assume that our suffering, our cares, our desires, and so on are opaque, even if we accept that they are not transparent. At best, they may be opaque relative to some standard. One wonders, however, what the standard is against which Stump judges various items to be not transparent and thus opaque. One can return to the contrast between pain and suffering to make progress here. One can tell whether one is in pain 'just by looking' as it were. Perhaps the claim is that one cannot tell by looking exactly what one desires or suffers and, thus, that suffering and its defeaters aren't transparent in whatever way that pain is.

One finds, upon closer inspection, that the comparison between pain and states related to suffering is more complicated than it may at first appear. No doubt one cannot fail to recognize one's pain for what it is when the pain is quite strong, one is undistracted, and the task at hand does not require one to identify the specific kind of pain or its cause. Relax any of these parameters, however, and the degree of transparency goes down. A slight pain to which one is not paying attention may fail to be identified at all or be mistaken for an itch. Someone with a motivation to believe that he is not in pain may be able to fool himself into believing that he is not so long as the pain is not of so acute or chronic a kind as to wear out his delusions. Furthermore, it may be transparent to one that one is in pain even though one cannot identify what kind of pain one is experiencing, cannot reliably compare that pain with other kinds of pain, or makes other mistakes about the pain's properties. These complications regarding pain narrow the gap between the transparency of pain and the lack of transparency of suffering and desire.

Just as pain is not completely transparent, so desire is not completely opaque. No doubt there are times when we make mistakes about what exactly it is that we care about or desire. We might not be able to tell exactly how much we care about something or exactly why we care about something. Being in the dark on some aspects of conative states is completely consistent with there being other features that are transparent. To return to the example of Tommy the teenager, it surely seems that there are a number of things that can be transparent to Tommy such as 
that he has a desire, that the object of this desire is Betty, and that the desire is of the romantic ilk. Desire contrasts with pain not in whether it is transparent but rather in how and to what extent it is transparent.

Instead of labelling types of mental state as transparent or opaque, it would be more apt to say that any given internal state has a transparency profile. The pain that one feels in one's toe upon stubbing it on the door jam scores high in the transparency of its cause and of the scope of the pain. The pattern of one's experience is such that the sudden onset of that kind of pain in those circumstances makes both the extent and the cause of the pain immediately apparent. The pain that comes from stubbing a toe may score high in the transparency of these features while scoring low in one's ability to know what 'defeats' the injury. The pain may go away gradually without one's being aware of the healing process internal to the toe. Thus, the cause and location of the pain is highly transparent for toe-stubbing, but the healing of the pain is more opaque. In contrast, it may be completely opaque to someone suffering from anxiety what the scope and cause of the anxiety is in a case where the defeat of the anxiety is transparent. Perhaps taking a certain medication or talking to one's child on the phone allays the anxiety in a way that is transparent despite the fact that the cause and scope of the anxiety had been fairly opaque.

The same holds true of our desires and what we care about. If Mary finds herself with a desire to have pecan praline ice cream, then some features of the desire may be more transparent and others may be more opaque. Perhaps she has no idea why she desires some ice cream at this particular time, but she might be aware that she values this ice cream because it reminds her of her mother. The desire for pecan praline ice cream may be less transparent to her the weaker the desire is and more clear as the desire increases in strength. In contrast, Mary's desire that her father give his toolkit to her instead of her brother might have a very different transparency profile. This desire might be more transparent to her if it is only a desire of moderate strength. She might be bemused to find that she really wants to get that toolkit and really wants her brother not to get it. The desire might become more opaque in some ways as this desire increases in strength. Perhaps when she feels the desire strongly she will lose conscious access to the contrastive nature of the desire, not being aware that she wants to best her brother in her father's attentions in the matter of the toolkit.

Consequently, the important question for Stump's theodicy is not whether suffering and the benefits that defeat it are completely transparent. 
Precious little is completely transparent. The important question rather is whether there are any general trends in the transparency profiles of suffering and defeaters of suffering that are relevant to Stump's project. With this background, let us take another look at Stump's theodicy and the purposes to which Stump puts her claims about transparency in the following two sections.

III.

In this section, I will argue that a nuanced version of transparency fits better into the worldview that forms the backdrop for Stump's theodicy.

For Aquinas and for Stump, goodness, truth, beauty, and being are all interconnected. In fact, they are all different ways for talking about the same thing. ${ }^{5}$ Beauty, for instance, is goodness made perceptible. ${ }^{6}$ The growth of a human being, the kind of growth that can defeat suffering, is a growth in integration around the good. On the assumption that one cannot have one of the transcendentals without having the others, however, growth in goodness must also be growth in truth and beauty. The growth of a human being in integration around the good is one from a fragmentation of mind and will into a unified whole. Because of the intimate connections between these transcendentals and because both truth and beauty have epistemic import, the telos of a human being includes a journey of mind as well as heart. One would expect the fragmentation of a soul to affect what truths one can reach and what goodness one is able to see.

It may be logically possible for a soul to go directly from a state of deep fragmentation to a state of complete union with God and thus with Goodness. Some have thought that such a transition will occur upon entrance into heaven. It seems undeniable, however, that this is not the case in this world. Growth in goodness is a gradual and treacherous affair. One would expect the epistemic dimensions of this journey to be gradual as well. A degreed notion of transparency fits neatly into this schema. There may be points on the journey of life when whole clusters of one's experience make sense for the first time where they were hopelessly

${ }^{5}$ Cf. Thomas Aquinas, Disputed Questions on Truth, J. McGlynn (tr.) (Chicago: H. Regenery Co., 1952), 1.1.

${ }^{6}$ Cf. Thomas Aquinas, Summa Theologiae, I, q.5, a.4 <www.newadvent.org/summa> [accessed April 5, 2012]. 
opaque previously. These moments are the exceptions, however. For the most part, clarity of perspective is something that comes on gradually. If this was the only advance that a more nuanced view of transparency brought, the gain might not be worth the effort to bring it to attention. More can be said, however.

An important question to ask is whether Stump's Thomistic theodicy has any implications for the transparency profiles of desires, beliefs about the satisfaction of our desires, and the like. Stump's picture of the psychological structure of the soul borrows heavily from Harry Frankfurt (cf. p. 132). She stresses that one's desires are hierarchical. The desires of the heart just are those desires that are most central to the web of one's desires. On Stump's account, however, human beings are deeply divided creatures. This inner alienation should show up in the hierarchy of one's desires. There are fault lines in the soul, and these fault lines should intersect the desires of the heart.

The brokenness of the human condition should manifest itself most profoundly within the desires of the heart because, from a Thomistic perspective, the human condition is one in which the soul is disordered. It is not the case that human beings desire things that should not be desired at all so much as that the hierarchy of desire fails to correspond to the hierarchy of goods that exist. The desires of the heart are, by definition, those desires most central and deeply embedded within the hierarchy of desire. Thus, these are the desires that are meant to correspond to the greatest goods. A failure of the desires of the heart to be properly ordered, then, would constitute an alienation from goodness more radical than a lack of proper order outside of this cluster of desires. On the Christian story, the human condition is one of just such a radical alienation from God and, thus, from goodness.

The structure of the soul and the way the human condition manifests itself within that structure implies that there are two competing considerations that should determine the transparency profile of our desires. One consideration is proximity to the centre of the web of desire; the other is proximity to fault lines within the soul. If all other things are equal, one would expect desires that are closer to the centre of the web to have enhanced transparency in many respects. They will command a greater portion of the intellect's attention due to their relative priority. The increased attention will be both quantitative and qualitative. Desires at the centre of one's web of desires should be more likely to be 
triggered in a variety of circumstances. One should also expect desires of higher priority to be felt more strongly in general, with more vivid phenomenology. Because of the fundamentality of these desires within one's value hierarchy, one would expect that more central desires will have a cluster of peripheral desires that can indirectly activate the more central desire but more peripheral desires will less regularly be activated by a cluster of more central desires.

Moreover, when a heart's desire is appropriately aimed at a good of sufficient weight, the intellect will be attending to a source of more truth and more perceptible goodness given the nature of transcendentals. The structure of the soul, then, should be such that, all other things being equal, transparency should be generally enhanced with increasing proximity to the centre of the web of desire, and it should decrease the farther away from the centre a desire is. All other things are not equal, however.

Proximity to a fault line in the soul should increase opacity. A division of the soul decreases the being, goodness, truth, and beauty in that part of the soul. The order in the soul fails to correspond to the order of objective goods, and, when it does so, one should find corresponding impairments in one's grasp of truth and one's perception of the good. ${ }^{7}$ To the extent that a desire is lodged in a more orderly part of the soul, the opacity caused by internal division will decrease relative to desires in less orderly parts of the soul. Once again, however, not all things are equal. The less divided parts of the soul are likely to be those parts of the soul on the outside of the web of desire, where desires are less inherently transparent under normal conditions.

These two competing considerations, proximity to the centre of the web of desire and proximity to divisions in the soul, should lead us to expect the transparency profiles of desires at different points of the web of desire to differ markedly in their properties. Desires that are farther from the centre should have more stable profiles, tending to score similarly on different dimensions of transparency. In general, the more attention one of these desires is given, the more transparent it should

${ }^{7}$ One might here think I am conflating the beauty of oneself with the beauty of the object of cognition. Beauty is goodness made perceptible, so a more beautiful mind will have more perceivable goodness. One might object, however, that it does not follow that the mind will perceive more goodness. The objector, however, forgets that the mind itself is the object of concern in the discussion of transparency. Because self-knowledge is at the fore here, an increase in the beauty of the mind is relevant to an increase in one's ability to perceive that beauty. 
become because the primary obstacle to transparency for such a desire is distance from the centre of one's attentions.

In contrast, a desire of the heart in a fallen human being should have a very uneven transparency profile because its position near the centre of the web of desire increases transparency while its proximity to the greatest divisions in the soul increases opacity and alienation from the truth. Because internal division is not complete, some things about these desires should have a high degree of transparency where the transparency lent to a desire by its position in the web is not defeated by internal division. Other aspects of the desire should be disproportionately opaque. A desire of the heart becoming stronger will not necessarily increase its transparency on balance. Rather, one would expect greater attention to exacerbate its uneven profile, heightening the transparency of parts of the desire while putting strain on the divisions of mind and will to which the desire is attached.

One can imagine the differences in these two kinds of desires with the following analogy. Imagine a field covered by magnets with more powerful magnets in the centre of the field and less powerful ones near the edges of the field. The more powerful magnets in the centre of the field have been fused to magnets with opposite orientations. A southnorth oriented magnet in the periphery would be by itself, but a more powerful south-north magnet in the centre of the field will be fused with a north-south magnet. When one passes a lodestone over the periphery of the field, the magnets tend to move weakly but uniformly due to their stable orientation and limited power. When the lodestone passes over the centre of the field, the magnets move strongly but unpredictably due to their unstable orientation and greater power. The difference between the relatively stable magnets on the periphery of the field and the more volatile magnets in the centre of the field is analogous to the way that position in the web of desire should affect the transparency profile of a desire given Stump's Thomistic metaphysics and Frankfurtian picture of psychic organization.

Position in the web of desire, then, should correspond with significant differences in the transparency profile of a desire. These differences lead to differences in how changes to the web of desire affect the transparency profiles of individual desires. Peripheral desires are less likely to change significantly in transparency as a result of one's overall growth in goodness unless growth in goodness also happens to move that desire deeper into the web. Presumably, more peripheral desires exist in more stable parts 
of the web, and the determining factor in their transparency profile is proximity to the centre of the web rather than proximity to divisions in the soul. In contrast, growth in goodness should affect exactly what inhibits the transparency of desires of the heart. To the extent that divisions in the soul heal, a desire of the heart should become more transparent in general and also acquire a more stable transparency profile.

This more nuanced perspective on transparency accords well with the biblical stories that Stump uses to support and fill out her position. Take, for instance, chapter twelve of Stump's book on Mary of Bethany (pp. 308-368).

Mary, the sister of Lazarus, feels that she has lost her heart's desire when Lazarus dies and Jesus fails to show up in time to save her brother. It is transparent to Mary early in the story that being separated from Lazarus is something that goes against the desires of her heart. It is transparent to Mary that Jesus could have kept her brother from dying, and it might be transparent to Mary that she wants Jesus to save her brother at least partly out of love of her. The story would not make sense unless Mary has a clear, unmistakable grasp of some of what she desires. The journey that Mary goes through in regaining her brother allows her to have the desires of her heart at a deeper level. It does not do so, however, in a way disconnected from Mary's perspective. What explains why we find Mary at Jesus' feet later in the story is the very fact that who Jesus is and how he relates to her and her desires has become more vivid to her than it was before Lazarus' illness. There are things that were opaque to her that have become clear. She knows this and responds out of love and gratitude.

Mutatis mutandis, the very same points hold of the stories of Samson, Abraham, and Job that Stump utilizes. The story of each of them only makes sense if one draws attention to the interplay of both transparency and opacity early in the story. Each story is one of coming to a place of increased transparency at the end of the story, not simply acquiescence in the face of unilateral opacity. Thus, I take it that a nuanced view of transparency accords better with both the 'Dominican' and the 'Franciscan' parts of Stump's book than a black and white account of transparency. The nuanced account fits better and might even logically follow from a Thomistic-Frankfurtian account of the divided and hierarchical soul. And the biblical stories that are at the heart of her project, such as the story of Mary, can be made better sense of with a nuanced view on which the selective transparency of each character's 
perspective at the beginning of the story blossoms into greater transparency by the end of the story.

Having made the case for amending Stump's position with a nuanced view of transparency, let us turn to the uses to which Stump had put her own claims on the topic.

\section{IV.}

As previously discussed, one use to which Stump puts her claims about transparency is diffusing tensions between sceptical theism and her theodicy. The sceptical theist wants to deny that we are in a position to assess the likelihood that God exists given the evils of this world. Stump declares some sympathy with this perspective, but she wants to make room for making substantive claims regarding what justifying reasons God actually has on the Christian story. Stump appeals to the opacity of one's suffering and defeaters of that suffering to preserve the sceptical theist's core conviction without thereby undercutting the possibility of giving a general account of some of God's reasons for allowing evil.

Moving to the more nuanced perspective on transparency would make the relationship between Stump's Thomistic theodicy and sceptical theism trickier. If it is not the case that suffering and the defeat of suffering is completely opaque, then one can be in a position to make some judgments about what evils the world contains and which ones might be defeated. If one can make some judgments about what evils are in the world and which ones might be defeated, then one can gather at least some evidence that surely seems relevant to the question of whether a good God could exist. It would not follow that one is in a position to gather sufficient evidence to be warranted in ruling out God's existence, but even this much of a concession to the autonomy of human reason would rub many sceptical theists the wrong way.

The dialectical advantage of a view on which transparency is an all or nothing affair is that one can use a lack of transparency as an impermeable barrier for one's opponent. If the form of the dialectic is such that one's opponent is attacking one's position, then having the ability to remove from the debate the evidence one's opponent wants to use is an especially useful defensive weapon. If suffering and its defeaters are completely opaque, then there is no room for the proponent of the argument from evil to haggle over the probability that God exists. The anti-theist loses the evidence needed to make an argument. 
Surely, however, gaining such an advantage over the anti-theist would be a pyrrhic victory. The problem of evil is a problem not because it is possible to posit something to which we have no access that is inconsistent with God's existence. Rather, the problem is that we are intimately acquainted with evil, and we are aware that its existence is in tension with the claim that a good and loving God exists. In order to have the knowledge that generates the problem in the first place, suffering can't be something that's opaque to us, not completely. Stump opens her book with the statement that only 'the most naïve or tendentious among us would deny the extent and intensity of suffering in the world' (p. 3). If suffering were opaque, however, there would be no basis for this claim. The fact that we all know the claim to be true should lead one to reject the opacity of suffering.

Adopting a nuanced perspective on transparency would not require denying that the sceptical theist has a point, however. On the enhanced version of Stump's theodicy developed in the previous section, there is a reason to expect systematic obstacles to gaining a full and balanced perspective on the exact nature of one's suffering. The greater someone suffers from division in her soul, the more limited her perspective on what is happening to her. It is worth remembering, however, that on the account developed here, greater suffering should correlate with a greater increase in clarity and insight should the divisions within the soul that cause that suffering be healed. In fact, unlike a position on which no humans are in a position to judge whether God and evil could co-exist, the nuanced view of transparency in conjunction with Stump's theodicy implies that some are in a good position to make this judgment, namely, those who have come through their sufferings much more integrated around the good. They, at least, are in a much better position to make these judgments than the rest of us. Surely, this result is more in harmony with Stump's readings of the biblical stories than a blanket denial of the aptness of human cognition for making progress on such matters.

Regarding Stump's second application of transparency, adopting a nuanced view of transparency would significantly restrict claims that the desires of someone's heart could be satisfied without one's awareness that this has happened. This restriction comes from two directions, one obvious and one less obvious. The more obvious consideration is that, on the nuanced view, some features of the desires of one's heart tend to be transparent. This opens up the possibility, for example, that Victor Klemperer really, really knew that what he desired to do was to write 
a book on French literature. One might tell Klemperer about what will happen to his diaries only to have him deny that this had anything to do with what he wanted, and, on the nuanced view of transparency, it's not unlikely that he is in a privileged epistemic position on the matter.

On a more general level, on the nuanced view of transparency, one has to take people's perspective on their desires more seriously than if the desires of the heart are all simply opaque to the people who have them. Attempting to explain away the heartbreak of frustrated desire by claiming that God could have secretly provided the desires of the sufferer's heart becomes a strategy of limited utility. This point accords well with Stump's biblical source material. Samson, Job, Abraham, and Mary all have problems of perspective early in their stories, but their problems do not amount to ignorance of the ways God has actually provided their heart's desire. Actually, they know that they are without their heart's desires early in the story, and, when God has satisfied those desires, they know it. This point brings us to the second and more subtle consideration.

Many of the desires of the heart should be such that the satisfaction of those desires is conditional upon some measure of healing in the soul. That inner healing, however, enhances one's epistemic position. As I argued in the last section, healing comes with increased transparency. Consequently, a soul that receives a desire of the heart should be in an improved epistemic position in relation to the status of that desire. Desires of the heart are supposed to take greater goods as objects. The greater the good, however, the more healing is necessary in order to appropriate that good. It is plausible that whatever divisions in the soul affect a desire of the heart at least overlap with the inner wounds that need healing in order for that desire to be fulfilled. Because the fulfilment of the desires of the heart should be correlated with growth in the transparency of these desires, one should expect that failures to recognize the genuine fulfilment of a desire of the heart should not often arise due to failures of self-knowledge. One might fail to know that a desire has been fulfilled for some other, extrinsic reason, but selfknowledge should not be the culprit.

One consequence of amending Stump's account in the manner I am recommending is that it opens up the possibility that the world is full of undefeated suffering from heartbreak. Many people suffer unfulfilled and deeply felt desires. If one cannot claim that these people simply have no epistemic access to whether or not their desires are fulfilled, then one is left with the question of what to do with genuine evidence for a vast amount 
of undefeated heartbreak. This is a significant cost, though it would not necessarily follow that such heartbreak makes belief in God untenable.

What might follow is that the first half of the psalmist's famous claim is very important. The psalmist says, 'Delight yourself in the Lord and He will give you the desires of your heart.' (Psalm 37:4) Becoming more integrated around goodness is a normal part of what is required to receive the desires of one's heart. This might be partly because it changes the desires of one's heart, but another reason is that inner healing is normally necessary to God's fulfilling one's deepest desires. Perhaps the prevalence of a lack of internal integration both in oneself and in others who are relevant to one's desires necessitates that God allow so much unresolved heartbreak in the here and now. No doubt developing the view in this way would be unpalatable to many, seeming to blame the heartbroken for their failing to receive what they desire or restricting what they may receive now due to the brokenness of others. Nonetheless, evolving the view in this way would appear to be faithful to the traditional Christian depiction of the human condition.

By way of conclusion, the characters in the biblical narratives Stump utilizes receive their heart's desire in a deeper way than they could have prior to an experience in which the object of desire seems to be taken from them. Why would this be if one's desires were opaque? How would almost losing one's deepest desire change one in the requisite way if that desire were opaque to one? I submit that it would not and could not. What actually happens in these stories is that the selective transparency of the characters' desires puts them in an uncomfortable half-light. As the story progresses, they find themselves moved towards the light, which comes with a greater ability to possess what they were searching for in the half-light. It is very important to recognize that half-light is not the light, but wandering in the half-light is also very different from wandering in total darkness.

Acknowledgement. The author would like to thank Godehard Brüntrup and an audience at the Hochschule für Philosophie as well as Eleonore Stump for comments and discussion. This publication was made possible through the support of a grant from the John Templeton Foundation, grant \#15571 ("Analytic Theology"). The opinions expressed in this publication are those of the author and do not necessarily reflect the views of the Templeton Foundation. 


\section{BIBLIOGRAPHY}

Aquinas, Thomas, Disputed Questions on Truth, J. McGlynn (tr.) (Chicago: H. Regenery Co., 1952)

Aquinas, Thomas, Summa Theologiae $<$ www.newadvent.org/summa $>$ [accessed April 5, 2012]

Howard-Snyder, Daniel (ed.), The Evidential Argument from Evil (Bloomington: Indiana University Press, 2009)

McBrayer, Justin, 'Skeptical Theism', Philosophy Compass, 5(7), (2010), 1-13 Stump, Eleonore, Wandering in Darkness: Narrative and the Problem of Suffering (New York: Oxford University Press, 2010) 